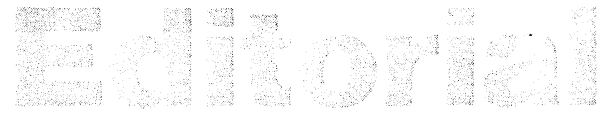

\section{Car Wars}

In my last editorial I referred to the use of (tax)subsidies and other incentives in the struggle for the international allocation of production. To illustrate this development there is probably no better example than the recent row between the French and UK government over the export of UK-built Nissan cars to France.

The United Kingdom has paid up to $£ 125$ million to have Nissan set up its plant in the United Kingdom and in return for this generous help secured from Nissan a commitment that its UKbuilt cars would contain 60 per cent EC content, rising to 80 per cent in 1991. The Nissan cars, to be exported to France, contain 70 per cent UK content. France, on the other hand, has limited Japanese car-makers to a 3 per cent of its home market and says that it will treat the UK-built cars as Japanese until less than 20 per cent of the value of the cars come from components imported from Japan.

The row highlights a number of important issues. First of all one may question, to put it mildly, the legitimacy of these unilaterally imposed quota (similar limitations exist in Italy and Spain) under both GATT and EC competition rules.

More important in the context of this Journal, however, is the question about the use of (tax)subsidies to attrack business activities. The (tax)subsidy game is, of course, by no means a new one. Least of all to the French. One may remember the rivalry between a number of European countries to attrack a Ford assembly plant in $1979 .{ }^{1}$ At the time the French government offered the equivalent of between $\$ 370$ million and $\$ 440$ million in an effort to persuade Ford to build the plant in France. Not, it must be said, to the amusement of French car makers. Direct investment within a common market is already relatively sensitive to regional (tax)subsidies. ${ }^{2}$ It can only be expected that this sensitivity will increase now the European Community moves towards a truly Single Market after 1992. At the same time the move to the Single Market has triggered a wave of direct investments. The competition between EC countries and regions to attrack these investments is intensive and turns sometimes into an unseemly auction. It is clear that, unless EC countries adopt some rules of the game, they risk being drawn into a scramble for national advantage.

Current EC rules allow up to about 30 per cent of capital expenditures in the form of straight subsidies for investments in development areas. Since 1971, when the finance ministers of the member countries produced a declaration of intent to submit harmonization programmes (including, by the end of 1973, a harmonization of allowances for depreciation, appreciation of assets, and related matters) little has been achieved in the corporate tax area. Earlier this year the European Commission produced a preliminary draft proposal for a directive which would harmonize the calculation of taxable profits by companies. When adopted the directive would no longer allow the tax-based subsidies now existing in many European countries. It is perhaps no news to anyone following the VAT rate harmonisation efforts that these corporate tax base proposals may have a long way to go. ${ }^{3}$

Finally there is the 'local content' issue. Wherever tariff and non-tariff barriers to trade play a role of any significance, rules to determine the 'origin' of goods are of the utmost importance. The EC has adopted in 1975 the rules of the Kyoto Convention where the test is whether the imported components were substantially transformed into a new article with a different character or identity. There are no hard and fast percentages rules when a 'substantial transformation' is supposed to occur. The Benelux rules, requiring 50 per cent Benelux value added, were considered to be too relaxed by other EC countries so the question was left open. Recent Community practice in disputes involving local content, for instance in a similar UK-Italian row over UK-made

1 See The Economist, "The investment incentives game', 20 January 1979, p. 72.

2 See Carl S. Shoup, 'Taxation of Multinational Corporations' (Corporate Tax Harmonization in Market Areas), New York 1974, p. 20 and Bernard Snoy, Taxes and Direct Inve'stment Income in the EEC: A Legal and Economic Analysis, New York 1975, 296.

3 See Richard Waters, "The evasive goal of company tax harmony". Financial Times, 19 September 1988. 
Honda's in 1982, has tended to use a 60 per cent yardstick, a figure largely plucked from thin air. More recently Japanese photocopier manufacturers faced EC anti-dumping duties for failing to keep the local content of their European produced copiers to an agreed level of 40 per cent. ${ }^{4}$

The wider spread of cross-border investment flows will make an EC rule setting minimum levels of local content inevitable. An 80 per cent EC content rule - suggested by European car-makers would surely be much too strict. In high-technology industries which draw on a multiplicity of sources for their final products, the rule would look most odd. In the global car industry, for instance, it would define virtually all Chryslers as non-American. ${ }^{5}$ In my country an aircraft manufacturer like Fokker, increasingly looking to the US for subcontractors (if only to protect the company against hectic currency fluctuations) would almost certainly not see its aircraft labelled as 'EC-made' (leave alone 'Dutch-made').

One may, therefore, hope for a more realistic (and less protectionist) approach of this issue. The outcome of the European car wars may give an indication of the regulation we may expect to take shape in the coming years.

In this issue of Intertax you will find an instructive article on 'Strategic planning in the field of custom duties', which, in the light of recent events, will be of particular interest. We hope you will enjoy this as well as the other articles.

Fred C. de Hosson Amsterdam, 19 October 1988

\footnotetext{
4 For a discussion of US issues: see Larlry T. Yanowitch, 'Foreign Assembly and Outsourcing: New Challenges to the Anti-dumping Law', 18 Law and Policy in International Business, 815 (1986).

5 The Economist, 'When "made-in-Europe" isn't', 8 October 1988, p. 73.
} 